\title{
Physiological Characteristics and GABA Production of Lactobacillus plantarum K255 Isolated from Kimchi
}

\author{
Sun-Young Park, Kee-Sung Kim, Myung-Ki Lee, and Sang-Dong Lim* \\ Korea Food Research Institute, Seongnam 463-746, Korea
}

\begin{abstract}
As a major inhibitory neurotransmitter of the central nervous system in animals, $\gamma$-aminobutyric acid (GABA) has several physiological functions, such as anti-hypertensive, diuretic, tranquilizer and anti-stress effects in human. In order to determine strains with high GABA producing ability and glutamate decarboxylase (GAD) activity, 273 bacteria were isolated from various types of Kimchi. Strain K255 contained $386.37 \mu \mathrm{g} / \mathrm{mL}$ of GABA in MRS broth containing 1\% MSG, 600.63 $\mu \mathrm{g} / \mathrm{mL}$ of GABA in MRS broth containing $2 \%$ MSG and $821.24 \mu \mathrm{g} / \mathrm{mL}$ of GABA in MRS broth containing 3\% MSG. It showed that $\mathrm{K} 255$ had the highest GABA production ability compared to other commercial lactic acid bacteria. K255 was identified as Lactobacillus plantarum based on its API carbohydrate fermentation pattern and 16S rDNA sequence. K255 was investigated for its physiological characteristics. The optimum growth temperature of $\mathrm{K} 255$ was $37^{\circ} \mathrm{C}$ and cultures took $13 \mathrm{~h}$ to reach the $\mathrm{pH} 4.4$. K255 showed more sensitive to bacitracin in a comparison of fifteen different antibiotics, and showed most resistance to kanamycin and vancomycin. Moreover, it was comparatively tolerant to bile juice and acid and displayed resistance to Escherichia coli, Salmonella Typhimurium, Staphylococcus aureus, with rates of 30.8\%, 29.7\%, and $23.4 \%$ respectively. These results demonstrate that K255 could be an excellent strain for the production of functional products.
\end{abstract}

Key words: Lactobacillus plantarum, physiological characteristics, $\gamma$-aminobutyric acid, functional product

\section{Introduction}

Kimchi is a Korean typical and traditional fermented food. Also, it has been in the top five healthy food in the world. Kimchi has abundant nutrient such as vitamin A, $\mathrm{B}$ and $\mathrm{C}$, minerals, high numbers of lactic acid bacteria (LAB) (Kim et al., 2007). Especially, LAB number could be extended during lactic acid fermentation in Kimchi. In Kimchi fermentation, the major anaerobic bacteria are Lactobacillus sakei, Leuconostoc mesenteroides, Lactobacillus brevis, Lactobacillus plantarum, Lactobacillus buchneri, Pediococcus pentasaceus, and Enterococcus faecalis (Cheigh and Park, 1994; Cho et al., 2006). Kimchi has various tastes and functionalities by LAB which release biologically active substances such as organic acid including lactic acid and $\gamma$-aminobutyric acid (GABA) (Hur et al., 2006; Kim et al., 2002; Oh et al., 2008).

GABA is a non-protein amino acid that is broadly distributed in nature (Manyam et al., 1981), and exists in

*Corresponding author: Sang-Dong Lim, Korea Food Research Institute, Seongnam 463-746, Korea. Tel: 82-31-780-9082, Fax: 82-31-780-9160, E-mail: limsd@kfri.re.kr brain and spinal cord of mammal. As a major inhibitory neurotransmitter of the central nervous system in animal, GABA has several physiological functions such as antihypertensive, diuretic, tranqulizer and anti-stress effects in human (Jakobs et al., 1993; Vaiva et al., 2004; Wong et al., 2003). Owing to numerous physiological functions of GABA, development of functional products containing GABA at high concentration has been actively performed (Saikusa et al., 1994; Tsushida and Murai, 1987).

GABA is mainly produced from irreversible $\alpha$-decarboxylation of L-glutamic acid (MSG), catalyzed by glutamic acid decarboxylase (GAD), which has been found in LAB (Ueno, 2000). It is expected that the ability to GABA production depends on the degree of activation of GAD which LAB has (Oh and Yu, 2011).

The aim of this study was to isolate and screen specific LAB which has great ability of GABA production from Kimchi for applying it to functional food products.

\section{Materials and Methods}

\section{Isolation of lactic acid bacteria}

Forty eight types of home-made and domestic Kimchi 
products were collected. Strain K255 was isolated from Kimchi in modified MRS medium (Lim et al., 2011). The strain was incubated in Lactobacilli MRS broth as the growth medium at $37^{\circ} \mathrm{C}$ for $18 \mathrm{~h}$.

\section{Measurement of GABA concentrations}

\section{Sample preparation}

Measurement of GABA concentrations was carried out as described by Zhang and Bown (1997). The strain was incubated in MRS broth containing L-glutamic acid (MSG) at $37^{\circ} \mathrm{C}$ for $18 \mathrm{~h}$. To measure the GABA concentrations, $100 \mu \mathrm{L}$ of the sample was mixed with $400 \mu \mathrm{L}$ of methanol at eppendorf tube, which was then thoroughly dried methanol at water bath set $70^{\circ} \mathrm{C}$. After methanol dried, $1 \mathrm{~mL}$ of $70 \mathrm{mM} \mathrm{LaCl}_{3}$ was added and mixed well. After centrifugation $(10,000 \mathrm{rpm} / 5 \mathrm{~min}), 700 \mu \mathrm{L}$ of the supernatant was mixed with $160 \mu \mathrm{L}$ of $0.1 \mathrm{M} \mathrm{KOH}$ in eppendorf tube and was agitated for $5 \mathrm{~min} .200 \mu \mathrm{L}$ of the supernatant which was centrifuged $(10,000 \mathrm{rpm} / 5 \mathrm{~min})$ was diluted 5 -fold with $0.5 \mathrm{M}$ potassium pyrophosphate buffer. $550 \mu \mathrm{L}$ of diluted solution was put in a cuvette.

Standard preparation and measurement of GABA concentrations

\begin{tabular}{|c|c|c|c|c|c|c|c|c|}
\hline $\begin{array}{l}\text { GABA } \\
(\mathrm{mM})\end{array}$ & 0 & 0.005 & 0.01 & 0.02 & 0.05 & 0.1 & $\begin{array}{l}\text { sam- } \\
\text { ple }\end{array}$ & blank \\
\hline $\begin{array}{l}\text { (1) } 1 \mathrm{mM} \\
\text { GABA }\end{array}$ & $\begin{array}{c}0 \\
(\mathrm{~mL})\end{array}$ & 0.005 & 0.01 & 0.02 & 0.05 & .1 & 0.55 & 0 \\
\hline $\begin{array}{l}\text { (2) } 0.5 \mathrm{M} \\
\mathrm{K}_{4} \mathrm{P}_{2} \mathrm{O}_{7}\end{array}$ & 1.75 & 0.745 & 0.74 & 0.73 & .7 & 0.65 & 0.2 & 0.75 \\
\hline $\begin{array}{l}\text { (3) } 4 \mathrm{mM} \\
\text { NADP }\end{array}$ & 0.15 & 0.15 & 0.15 & 0.15 & 0.15 & 0.15 & 0.15 & 0.15 \\
\hline $\begin{array}{l}\text { (4) } 2.0 \text { units } \\
\text { Gabase } / \mathrm{mL}\end{array}$ & 0.05 & 0.05 & 0.05 & 0.05 & 0.05 & 0.05 & 0.05 & 0.05 \\
\hline $\begin{array}{c}\text { (5) } 20 \mathrm{mM} \\
\alpha-\mathrm{KG}\end{array}$ & 0.05 & 0.05 & 0.05 & 0.05 & 0.05 & 0.05 & 0.05 & 0.05 \\
\hline
\end{tabular}

(1), (2), (3) and (4) were mixed and measured its absorbance at $340 \mathrm{~nm}$ (initial A). After measurement, $50 \mu \mathrm{L}$ of $20 \mathrm{mM} \alpha-\mathrm{KG}$ was added each cuvette and stayed for an hour at room temperature. And then measured final absorbance at $340 \mathrm{~nm}$ (final A). Concentrations of GABA were determined using the following formula:

$$
\operatorname{GABA}(\mu \mathrm{g} / \mathrm{mL})=\left(\frac{\text { Final A }- \text { Initial A }}{\text { Standard curve }} \times \frac{100}{70} \times \frac{86}{55}\right) \times 5 \times 10
$$

\section{Identification of strain $\mathbf{K} 255$}

The properties of the strain K255 was investigated by testing the Gram staining and microscopic observation after cultivation on tryptic soy agar for $24 \mathrm{~h}$ at $37^{\circ} \mathrm{C}$. Bergey's Manual of Systematic Bacteriology by Buchanan and Gibbons (1974) was used to examine the morphological and physiological properties of the isolated strains. K255 strain was identified by using the $16 \mathrm{~S}$ rDNA sequencing method. Chromosomal DNA of isolated strain was separated by using SolGent Genomic DNA prep kit (SolGent, Korea). The DNA extracts were used for polymerase chain reaction (PCR) with the universal primers [27F (5'-AGA GTT TGA TCC TGG CTC AG-3') and 1492R (5'-GGT TAC CTT GTT ACG ACT T-3')]. PCR were carried out in a programmable thermo cycler (Solgent EF-Taq, Korea), with the following steps: one cycle of denaturation at $95^{\circ} \mathrm{C}$ for $15 \mathrm{~min}, 30$ cycles of $95^{\circ} \mathrm{C}$ for $20 \mathrm{~s}, 50^{\circ} \mathrm{C}$ for $40 \mathrm{~s}$ and $72^{\circ} \mathrm{C}$ for $90 \mathrm{~s}$ were performed. Final extension was carried out at $72^{\circ} \mathrm{C}$ for $5 \mathrm{~min}$. PCR product purified by using SolGent PCR purification kit (SolGent, Korea) was used for sequencing with $\mathrm{ABI}$ 3730XL DNA analyzer (Applied Biosystems, USA).

\section{Growth of strain}

The number of viable $L$. plantarum K255 was determined by serial 10 -fold dilution in $0.1 \%$ peptone water. $L$. plantarum $\mathrm{K} 255$ was inoculated $50 \mu \mathrm{L}\left(9.6 \times 10^{5} \mathrm{CFU} / \mathrm{mL}\right)$ into $150 \mathrm{~mL}$ of MRS broth. And then culture was incubated to $3 \mathrm{~h}$ interval for $24 \mathrm{~h}$ at $34^{\circ} \mathrm{C}, 37^{\circ} \mathrm{C}$ and $40^{\circ} \mathrm{C}$. All pour plates were incubated aerobically at $37^{\circ} \mathrm{C}$ for $48 \mathrm{~h}$ using BCP plate count agar.

\section{Antibiotic tolerance}

L. plantarum $\mathrm{K} 255$ was grown at $37^{\circ} \mathrm{C}$ for $18 \mathrm{~h}$ in MRS broth and inoculated (1\%, v/v) in Tryptic soy broth (Difco, USA) supplemented with antibiotics (amikacin, gentamicin, kanamycin, neomycin, streptomycin, penicillin-G, methicillin, oxacillin, ampicillin, bacitracin, rifampicin, novobiocin, lincomycin, polymyxin B, and chloramphenico; Sigma) at various concentrations of 2-fold dilution step. Minimal inhibitory concentration (MIC) was determined by the checking the moment of the strain stop growing after incubation at $37^{\circ} \mathrm{C}$ for $48 \mathrm{~h}$.

\section{Enzyme activity}

The API ZYM kit (bioMerieux, France) was used to study enzyme activity. L. plantarum K255 was grown at $37^{\circ} \mathrm{C}$ for $18 \mathrm{~h}$ on MRS broth. Sediment from centrifuged broth culture was used to prepare the suspension at $10^{5}$ $10^{6} \mathrm{CFU} / \mathrm{mL}$. After inoculation, cultures were incubated for $5 \mathrm{~h}$ at $37^{\circ} \mathrm{C}$. Placing a surface active agent (ZYM A 
reagent) in the cupules facilitated solubilization of the ZYM $B$ reagent in the medium. Color was allowed to develop for at least $5 \mathrm{~min}$, and values from 0-5 corresponding to the colors developed, were assigned. The approximate number of free nmol hydrolyzed substrate was determined based on the color strength: 0 , negative reaction; $1,5 \mathrm{nmol} ; 2$, $10 \mathrm{nmol} ; 3,20 \mathrm{nmol}$ 4, $30 \mathrm{nmol} ; 5,40$ or higher.

\section{Bile tolerance}

Bile tolerance was carried out as described by Gilliland and Walker (1990). L. plantarum K255 was grown at $37^{\circ} \mathrm{C}$ for $18 \mathrm{~h}$ on the MRS broth. Culture of L. plantarum K255 was compared for their ability to grow in the presence of bile by individual inoculation ( $1 \%$ ) into sterile MRS broth containing $0.05 \%$ L-cysteine with and without $0.3 \%$ oxgall. After plating for initial counts, mixtures were incubated anaerobically for $7 \mathrm{~h}$ at $37^{\circ} \mathrm{C}$. L. plantarum K255 was then enumerated again to test the survival rates after $7 \mathrm{~h}$ incubation. All pour plates were incubated anaerobically for $48 \mathrm{~h}$ at $37^{\circ} \mathrm{C}$.

\section{pH tolerance}

$\mathrm{pH}$ tolerance was carried out as described by Clark et al. (1993). Solutions of $37 \% \mathrm{HCl}$ in double-distilled water were adjusted to $\mathrm{pH}$ level to 2.0, 3.0, and 4.0. Sterile double-distilled water ( $\mathrm{pH}$ 6.4) served as the control. $10 \mathrm{~mL}$ of each $\mathrm{pH}$ solution were transferred into sterile test tubes. $1 \mathrm{~mL}$ of stock culture containing approximately $10^{9} \mathrm{CFU} /$ $\mathrm{mL}$ of L. plantarum K255 using MRS agar containing $0.05 \%$ cysteine was then transferred into each of the four $\mathrm{pH}$ solutions. The $\mathrm{pH}$ solutions containing L. plantarum $\mathrm{K} 255$ were then incubated anaerobically at $37^{\circ} \mathrm{C}$, followed by intermittent plating after 1,2 , and $3 \mathrm{~h}$ to stimulate survival of $L$. plantarum $\mathrm{K} 255$ under $\mathrm{pH}$ conditions common to the human stomach. Samples from the $\mathrm{pH}$ solution were taken at 1,2, and $3 \mathrm{~h}$ after the samples was suspended again and subjected to serial dilutions. About $100 \mu \mathrm{L}$ above sample solution was spread onto the surface of BCP plate count agar plates and incubated anaerobically at $37^{\circ} \mathrm{C}$ for $48 \mathrm{~h}$.

\section{Antimicrobial activity}

Antimicrobial activity test was carried out as described by Gilliland and Speck (1977). Escherichia coli KFRI 174, Salmonella Typhimurium KFRI 250, Staphylococcus aureus KFRI 219 were from the culture collection of the Korea Food Research Institute. Escherichia coli was enumerated on EMB agar, Salmonella Typhimurium on Bismuth sulfite agar, and Staphylococcus aureus on Baird parker agar. All plate were incubated $48 \mathrm{~h}$ at $37^{\circ} \mathrm{C}$. The control and associative culture were incubated for $6 \mathrm{~h}$ in a water bath at $37^{\circ} \mathrm{C}$. At the end of the incubation time, samples were removed and placed in an ice bath until analyzed. The number of CFU of pathogens per $\mathrm{mL}$ was determined using the appropriate selective medium and in some experiments the $\mathrm{pH}$ of the samples was also measured. Percentages of inhibition were determined by the following formula:

$$
\text { Inhibition }(\%)=
$$

$\underline{(\mathrm{CFU} / \mathrm{mL} \text { in control })-(\mathrm{CFU} / \mathrm{mL} \text { in associative culture })} \times 100$ (CFU/mL in control)

\section{Statistical analysis}

The results were expressed as the mean \pm standard deviation (SD). The statistical analysis was performed with the Statistical Package for Social Sciences (SPSS, SPSS Inc., Chicago, IL, USA). The significance of the differences was analyzed by using one-way analysis of variance (ANOVA) with Duncan's multiple range tests. Value of $p<0.05$ were considered as statistically significant.

\section{Results and Discussion}

\section{Isolation of lactic acid bacteria}

Forty eight kinds of home-made and domestic Kimchi products were collected. Total 273 strains were isolated as lactic acid bacteria from Kimchi in the modified MRS medium.

\section{Selection of lactic acid bacteria producing GABA}

After incubation of MRS broth containing 2\% MSG at $37^{\circ} \mathrm{C}$ for $18 \mathrm{~h}$, Seventy five strains over $50 \mu \mathrm{g} / \mathrm{mL}$ of GABA containing were selected from 273 strains by the measurement of GABA concentrations. GABA concentrations of Seventy five strains were repeatedly measured in triplicate. Nine strains over $90 \mu \mathrm{g} / \mathrm{mL}$ of GABA containing were selected and incubated in MRS broth containing $1 \%, 2 \%$ and $3 \% \mathrm{MSG}$ at $37^{\circ} \mathrm{C}$ for $18 \mathrm{~h}$ (Table 1 ). As a result, K255 was selected which contained 386.37 $\mu \mathrm{g} / \mathrm{mL}$ of GABA in MRS broth containing $1 \% \mathrm{MSG}$, $600.63 \mu \mathrm{g} / \mathrm{mL}$ of GABA in MRS broth containing $2 \%$ MSG and $821.24 \mu \mathrm{g} / \mathrm{mL}$ of GABA in MRS broth containing 3\% MSG. It was higher level compared to the commercial strains which producing $5-30 \mu \mathrm{g} / \mathrm{g}$ D.W of GABA. Bae et al. (2009) has reported that Lactobacillus sp. OPK2-59 strain isolated from Kimchi produced 390 
Table 1. $\mathrm{pH}$ and GABA content produced after incubation at $37^{\circ} \mathrm{C}$ for $18 \mathrm{hr}$ in the MRS broth added monosodium glutamate and $1 \%$ lactic acid bacteria

\begin{tabular}{ccccccc}
\hline \hline \multirow{2}{*}{ Strains } & \multicolumn{2}{c}{$1 \%$ MSG } & \multicolumn{2}{c}{$2 \%$ MSG } & \multicolumn{2}{c}{$3 \%$ MSG } \\
\cline { 2 - 7 } & GABA $(\mu \mathrm{g} / \mathrm{mL})$ & $\mathrm{pH}$ & GABA $(\mu \mathrm{g} / \mathrm{mL})$ & $\mathrm{pH}$ & GABA $(\mu \mathrm{g} / \mathrm{mL})$ & $\mathrm{pH}$ \\
\hline K13 & $86.70 \pm 12.41^{\mathrm{d}}$ & 4.03 & $117.56 \pm 8.48^{\text {def }}$ & 4.18 & $187.71 \pm 4.69^{\text {cd }}$ & 4.4 \\
K61 & $64.13 \pm 7.16^{\mathrm{e}}$ & 4.07 & $107.76 \pm 12.66^{\mathrm{f}}$ & 4.18 & $150.16 \pm 16.25^{\mathrm{e}}$ & 4.42 \\
K63 & $101.67 \pm 5.41^{\mathrm{c}}$ & 4.05 & $140.42 \pm 2.82^{\mathrm{c}}$ & 4.22 & $192.40 \pm 4.69^{\mathrm{c}}$ & 4.37 \\
K67 & $82.90 \pm 2.70^{\mathrm{d}}$ & 4.05 & $128.99 \pm 7.48^{\mathrm{cd}}$ & 4.43 & $154.86 \pm 4.69^{\mathrm{e}}$ & 4.47 \\
K71 & $89.16 \pm 4.69^{\mathrm{d}}$ & 4.01 & $109.40 \pm 2.82^{\text {ef }}$ & 4.14 & $186.14 \pm 2.70^{\mathrm{c}}$ & 4.44 \\
K74 & $134.52 \pm 10.83^{\mathrm{b}}$ & 4.13 & $212.27 \pm 7.48^{\mathrm{b}}$ & 4.30 & $234.63 \pm 24.38^{\mathrm{b}}$ & 4.43 \\
K170 & $76.64 \pm 2.70^{\mathrm{d}}$ & 4.04 & $94.31 \pm 4.96^{\mathrm{g}}$ & 4.18 & $153.29 \pm 5.41^{\mathrm{e}}$ & 4.44 \\
K173 & $62.57 \pm 2.70^{\mathrm{e}}$ & 4.15 & $120.78 \pm 7.58^{\mathrm{de}}$ & 4.25 & $159.49 \pm 2.70^{\text {de }}$ & 4.55 \\
K255 & $386.37 \pm 15.08^{\mathrm{a}}$ & 4.13 & $600.63 \pm 4.96^{\mathrm{a}}$ & 4.24 & $821.24 \pm 12.41^{\mathrm{a}}$ & 4.49 \\
\hline
\end{tabular}

All values are mean \pm standard deviation of three replicates.

${ }^{a-g}$ Means values with different superscript within same proportion of MSG are significantly different $(p<0.05)$.

$\mu \mathrm{g} / \mathrm{g}$ GABA in MRS media containing 1\% MSG. K255 strain was similar in GABA production ability to the $L a c$ tobacillus sp. OPK2-59 strain.

\section{Identification and DNA sequencing of selected strain K255}

The physiological and biochemical test was done to determine the genus and species of selected K255 strain. Selected K255 strain was non-spore, rod type, hetero fermentative, gram positive bacteria and exhibited negative properties on catalase and motility. Also, K255 strain can grow at $15^{\circ} \mathrm{C}$ and $45^{\circ} \mathrm{C}$. It does not produce gas and ammonia from glucose and arginine so that it was identified as a genus Lactobacillus (Table 2). Identification using the $16 \mathrm{~S}$ rDNA sequencing method by the PCR of universal primer was result in the Lactobacillus plantarum with possibility of $99 \%$ (data not shown). Based upon the result of previous study, it has named as a Lactobacillus plantarum K255.

\section{Growth of strain}

The number of viable L. plantarum K255 was determined by serial 10 -fold dilution in $0.1 \%$ peptone water. $50 \mu \mathrm{L}\left(9.6 \times 10^{5} \mathrm{CFU} / \mathrm{mL}\right)$ of $L$. plantarum K255 was inoculated in $150 \mathrm{~mL}$ of MRS broth. And then culture was incubated at $34^{\circ} \mathrm{C}, 37^{\circ} \mathrm{C}$ and $40^{\circ} \mathrm{C}$ for $24 \mathrm{~h}$ by checking $3 \mathrm{~h}$ and highest growth rate was found at $34^{\circ} \mathrm{C}$. The optimum growth temperature of L. plantarum $\mathrm{K} 255$ was $37^{\circ} \mathrm{C}$ and it has taken $13 \mathrm{~h}$ to reach the $\mathrm{pH} 4.4$ under this condition (Fig. 1, Fig. 2).

\section{Antibiotic tolerance}

It is very important for the probiotic strain can survive in the antibiotic circumstance. Table 3 shows the tolerance of L. plantarum K255 strain on the sixteen kinds of anti-
Table 2. Physiological characteristics of L. plantarum K255

\begin{tabular}{|c|c|c|c|}
\hline \multicolumn{2}{|l|}{ Gram reaction } & \multicolumn{2}{|l|}{+} \\
\hline \multicolumn{2}{|l|}{ Cell type } & \multicolumn{2}{|l|}{ rod } \\
\hline \multicolumn{2}{|l|}{ Spore forming } & \multicolumn{2}{|l|}{-} \\
\hline \multicolumn{2}{|l|}{ Motility } & \multicolumn{2}{|l|}{-} \\
\hline \multicolumn{2}{|l|}{ Aerobic growth } & \multicolumn{2}{|l|}{+} \\
\hline \multicolumn{2}{|l|}{ Anaerobic growth } & \multicolumn{2}{|l|}{+} \\
\hline \multicolumn{2}{|l|}{ Catalase reaction } & \multicolumn{2}{|l|}{-} \\
\hline \multicolumn{2}{|l|}{ Growth at $15^{\circ} \mathrm{C}$} & \multicolumn{2}{|l|}{+} \\
\hline \multicolumn{2}{|l|}{ Growth at $45^{\circ} \mathrm{C}$} & \multicolumn{2}{|l|}{+} \\
\hline \multirow{3}{*}{\multicolumn{2}{|c|}{$\begin{array}{l}\text { Gas forming from glucose } \\
\text { Ammonia production from alginin } \\
\text { Acid production from }\end{array}$}} & \multicolumn{2}{|l|}{-} \\
\hline & & \multicolumn{2}{|l|}{-} \\
\hline & & & \\
\hline Glycerol & - & Salicin & + \\
\hline Erythritol & - & D-Celiobiose & + \\
\hline D-Arabinose & - & D-Maltose & + \\
\hline L-Arabinose & - & D-Lactose & + \\
\hline D-Ribose & + & D-Melibiose & + \\
\hline D-Xylose & - & D-Saccharose & + \\
\hline L-Xylose & - & D-Trehalose & + \\
\hline D-Adonitol & - & Inulin & - \\
\hline Methyl- $\beta D$-Xylopyranoside & - & D-Melezitose & - \\
\hline D-Galactose & + & D-Raffinose & + \\
\hline D-Glucose & + & Amidon(starch) & - \\
\hline D-Fructose & + & Glycogen & - \\
\hline D-Mannose & + & Xylitol & - \\
\hline L-Sorbose & - & Gentiobiose & + \\
\hline L-Rhamnose & - & D-Turanose & - \\
\hline Dulcitol & - & D-Lyxose & - \\
\hline Inositol & - & D-Tagatose & - \\
\hline D-Mannitol & + & D-Fucose & - \\
\hline D-Sorbitol & + & L-Fucose & - \\
\hline Methyl-aD-Mannopyranoside & + & D-Arabitol & - \\
\hline Methyl-aD-Glucopyranoside & - & L-Arabitol & - \\
\hline N-AcetylGlucosamine & + & otassium Gluconate & - \\
\hline Amygdalin & + Potas & ssium 2-KetoGluconate & - \\
\hline Arbutin & + Potas & ssium 5-KetoGluconate & - \\
\hline Esculin & + & & \\
\hline
\end{tabular}

biotics. L. plantarum K255 showed more sensitive to bac- 


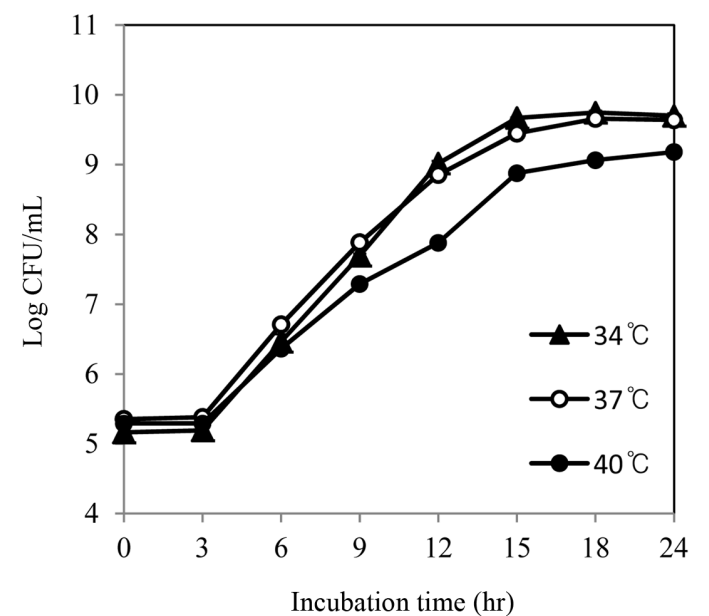

Fig. 1. Growth of Lactobacillus plantarum K255 in MRS broth at various temperature.

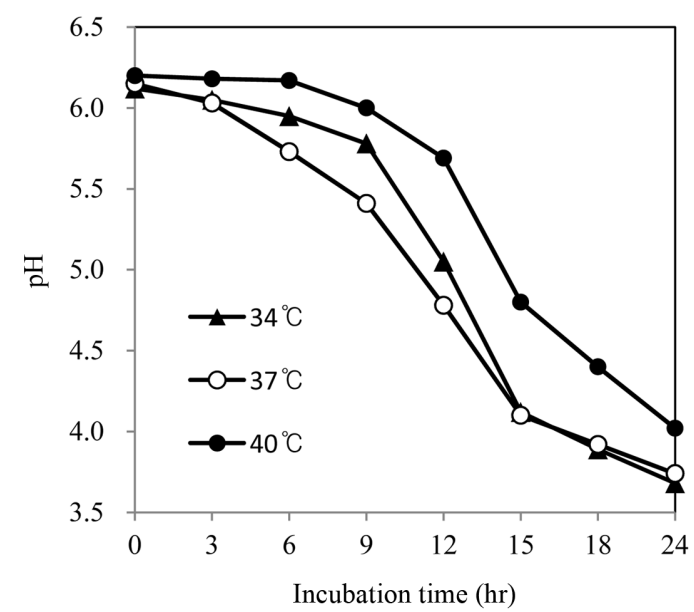

Fig. 2. pH changes of MRS broth during the growth of Lactobacillus plantarum K255 in MRS broth at various temperature.

itracin in a comparison of fifteen different antibiotics, and showed most resistance to kanamycin and vancomycin.

Kim et al. (2010) has reported that L. plantarum TJ-LP002 isolated from phakimchi was sensitive to streptomycin sulfate but it shown high resistance to neomycin sulfate, spectinomycin dihydrochloride and lincomycin hydrochloride. According to Rojo-Bezares et al. (2006), the minimal inhibitory concentrations of antibiotics against $L$. plantarum strains isolated from wine were, respectively, the following ones: penicillin $(0.5-4 \mu \mathrm{g} / \mathrm{mL})$, chloramphenicol $(4-16 \mu \mathrm{g} / \mathrm{mL})$, vancomycin $(128 \mu \mathrm{g} / \mathrm{mL})$, streptomycin $(16-512 \mu \mathrm{g} / \mathrm{mL})$, gentamicin $(32-128 \mu \mathrm{g} / \mathrm{mL})$, kanamycin $(128-1024 \mu \mathrm{g} / \mathrm{mL})$. These results showed higher susceptibility against antibiotics than L. plantarum K255
Table 3. Antibiotics susceptibility of Lactobacillus plantarum K255

\begin{tabular}{lc}
\hline \hline $\begin{array}{c}\text { Antimicrobal } \\
\text { agents }\end{array}$ & $\begin{array}{c}\text { minimal inhibitory concentrations } \\
(\mu \mathrm{g} / \mathrm{mL})\end{array}$ \\
\hline Aminoglycosides & $160 \pm 0$ \\
Amikacin & $1280 \pm 0$ \\
Gentamycin & $3200 \pm 0$ \\
Kanamycin & $800 \pm 0$ \\
Neomycin* & $1600 \pm 0$ \\
Streptomycin & $160 \pm 0$ \\
\hline$\beta$-lactams & $320 \pm 0$ \\
Penicillin-G* & $240 \pm 0$ \\
Methicillin & $320 \pm 0$ \\
Oxacillin & $15 \pm 0$ \\
Ampicillin & $480 \pm 0$ \\
\hline Gram-positive spectrum & $120 \pm 0$ \\
Bacitracin* & $800 \pm 0$ \\
Rifampicin & \\
Novobiocin & $2400 \pm 0$ \\
Lincomycin* & $320 \pm 0$ \\
\hline Gram-negative spectrum & $3200 \pm 0$ \\
Polymyxin B* & \\
\hline Broad spectrum & \\
Chloramphenicol & Vancomycin \\
\hline
\end{tabular}

*units/mL.

All values are meantstandard deviation of three replicates.

strain.

\section{Enzyme activity}

The enzyme activity is important for the selection of probiotic strain, because microorganisms can produce carcinogenic enzyme such as $\beta$-glucuronidase (Beaud et al., 2005). L. plantarum K255 did not produce the $\beta$-glucuronidase. The enzymes produced by L. plantarum K255 were esterase, esterase lipase, leucine arylamidase, valine arylamidase, crystine arylamidase, acid phosphatase, naphtol-AS-BIphosphohydrolase, $\alpha$-galactosidase, $\beta$-galactosidase, $\alpha$-glucosidase, $\beta$-galactosidase, and $\mathrm{N}$-acetyl $\beta-$ glucosaminidase. Especially, leucine arylamidase, $\beta$-galactosidase, $\beta$-glucosidase, $\mathrm{N}$-acetyl- $\beta$-glucosaminidase activity was 5 degree.

This result is comparable trends to the report of Lee et al. (2008) on the $\beta$-glucuronidase activity of $L$. acidophilus A12. Also, the enzyme profiles of $L$. plantarum K255 strain were similar to the L. plantarum isolated from fermented ewe's milk (Medina et al. 2001) except alkaline phosphatase and $\mathrm{N}$-acetyl- $\beta$-glucosaminidase.

\section{Bile tolerance}

Bile salts are toxic effect for living cells, since they dis- 
Table 4. Enzyme patterns of Lactobacillus plantarum $\mathrm{K} 255$

\begin{tabular}{cc}
\hline \hline Enzyme & L. plantarum K255 \\
\hline Alkaline phosphatase & 0 \\
Esterase (C4) & 1 \\
Esterase Lipase (C8) & 1 \\
Lipase (C14) & 0 \\
Leucine arylamidase & 5 \\
Valine arylamidase & 4 \\
Cystinearylamidase & 1 \\
Trypsin & 0 \\
$\alpha$-chymotrypsin & 0 \\
Acid phosphatase & 2 \\
$\alpha$-galactosidase & 2 \\
$\beta$-galactosidase & 1 \\
$\beta$-glucuronidase & 5 \\
$\alpha$-glucosidase & 0 \\
$\beta$-glucosidase & 0 \\
$\alpha$-acetyl- $\beta$-glucosaminidase & 4 \\
$\alpha$-mannosidase & 5 \\
$\alpha$-fucosidase & 5
\end{tabular}

*A value ranging from 0 to 2 is assigned to the standard color, Zero represents a negative ; 5 represent a reaction of maximum intensity. Values 1 through 4 represent intermediate reactions depending on the level of intensity. The approximate activity may be estimated from the color strenght ; 1 corresponds to the liberation of 5 nanomoles, 2 to 10 nanomoles, 3 to 20 nanomoles, 4 to 30 nanomoles and 5 to 40 nanomoles or more.

organize the structure of the cell membrane and bile salt tolerance is considered one of the essential properties required for lactic acid bacteria to survive in the small intestine (Succi et al., 2005).

Fig. 3 shows growth curves in MRS broth or MRS broth containing $0.3 \%$ bile. The log value of population after $7 \mathrm{~h}$ incubation without $0.3 \%$ oxgall was 9.1 but 8.6 with the addition of $0.3 \%$ bile. Therefore, the survival rate of L. plantarum K255 in MRS broth containing 0.3\% bile was $90 \%$. This survival rate is relatively high compared with the report of Kim et al. (2010) on the bile tolerance of L. plantarum TJ-LP-002 isolated from phakimchi. The survival rate of $L$. plantarum TJ-LP-002 in MRS broth containing $0.3 \%$ bile was $54.76 \%$.

\section{Acid tolerance}

In order to survive in the gastrointestinal tract, the strain should express high tolerance to acid (Kirjavainen et al., 1998; Lee and Salminen, 1995). To be a good probiotic, it is necessary to survive in the $\mathrm{pH}$ lower than 3 so that it could reach to the small intestine through the stomach (Booth, 1985; Mcdonald et al., 1990). The acid tolerance of lactic acid bacteria has been linked to the induction of $\mathrm{H}^{+}$-ATPase activity (Matsumoto et al., 2004; Ventura et

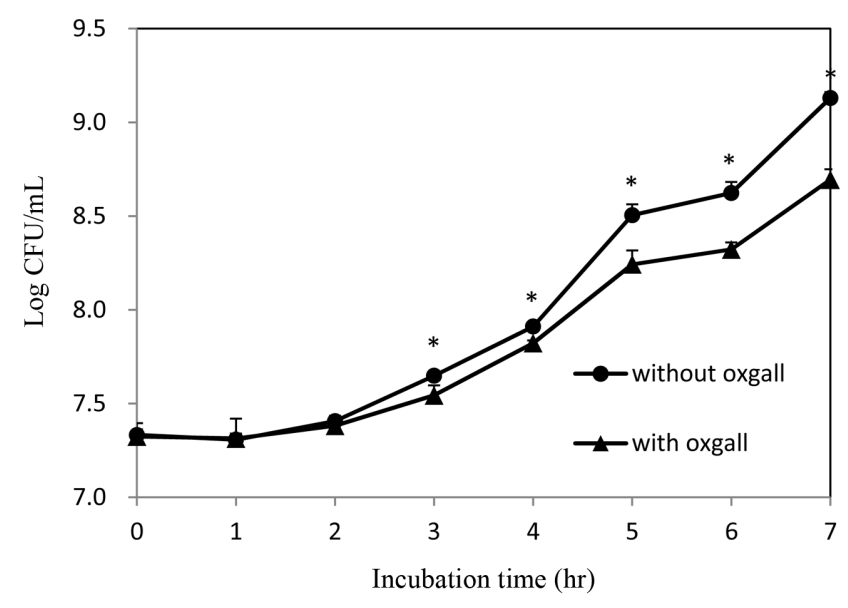

Fig. 3. Growth of Lactobacillus plantarum K255 in MRS broth containing $0.05 \%$ L-cysteine with/without $0.3 \%$ oxgall. ${ }^{*} p<0.05$ between with oxgall and without oxgall.

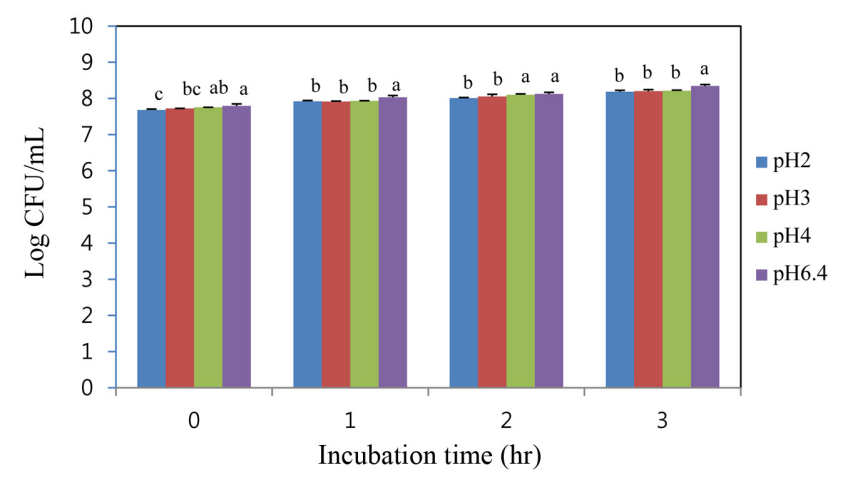

Fig. 4. Survival of Lactobacillus plantarum K255 after three hours in HCl solution (pH 2.0, 3.0, 4.0 and 6.4). ${ }^{\mathrm{a}-\mathrm{c}}$ Means values with different superscript within same time are significantly different $(p<0.05)$.

al., 2004). Therefore, the variation in the acid tolerance of the selected probiotics might be related to the difference in $\mathrm{H}^{+}$-ATPase activity in the probiotics. Fig. 4 shows the $\mathrm{pH}$ tolerance of $L$. plantarum K255. At the $\mathrm{pH} 2$, The log value of population had increased from 7.68 to 8.18 after 3 hours incubation. Bacterial growth of $L$. plantarum K255 at $\mathrm{pH}$ 2-4 was not increased significantly compared to $\mathrm{pH}$ 6.4. And this result is comparable to the result of Jeon et al. (2007) that the cell density of $5.0 \times 10^{6} \mathrm{CFU} / \mathrm{mL}$ at $\mathrm{pH}$ 3 was decreased to $1.7 \times 10^{1} \mathrm{CFU} / \mathrm{mL}$ after 3 hours incubation.

\section{Antimicrobial activity}

The antimicrobial ability is one of important property for probiotics. The antimicrobial activity of lactic acid bacteria may be due to a number of factors. Table 5 shows 
Table 5. Inhibition of pathogens by Lactobacillus plantarum K255 in MRS broth

\begin{tabular}{cccc}
\hline \hline pathogens & pathogens $^{\text {a }}$ & L. plantarum $\mathrm{K} 255^{\text {a }}+$ Pathogens & Inhibition (\%) \\
\cline { 2 - 4 } & $\mathrm{CFU} / \mathrm{mL}$ & $\mathrm{CFU} / \mathrm{mL}$ & $30.8 \pm 3.6$ \\
Escherichia coli & $5.8 \times 10^{4} \pm 0.6 \times 10^{4}$ & $4.0 \times 10^{4} \pm 0.3 \times 10^{4}$ & $29.7 \pm 5.7$ \\
Salmonella Typhimurium & $4.8 \times 10^{5} \pm 0.7 \times 10^{5}$ & $3.4 \times 10^{5} \pm 0.2 \times 10^{5}$ & $22.7 \pm 12.6$ \\
Staphyloccous aureus & $2.2 \times 10^{6} \pm 0.5 \times 10^{6}$ & $1.7 \times 10^{6} \pm 0.2 \times 10^{6}$ & \\
\hline
\end{tabular}

*Initial count of L. plantarum $\mathrm{K} 255$ : $3.4 \times 10^{6} \pm 0.5 \times 10^{6} \mathrm{CFU} / \mathrm{mL}$

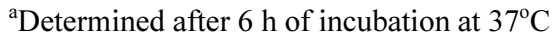

All values are mean \pm standard deviation of three replicates.

the antimicrobial activity of $L$. plantarum K255 against the pathogenic strains. L. plantarum K255 showed resistence against $E$. coli, $S$. Typhimurium and $S$. aureus with the rate of $30.8 \%, 29.7 \%$, and $23.4 \%$ respectively.

Kim et al. (2010) has reported that L. casei CU2064 has antimicrobial activity on the E. coli, $S$. Typhimurium and $S$. aureus with the rate of $86.89 \%, 85.00 \%$ and $82.50 \%$ respectively. L. plantarum K255 has relatively low antimicrobial activity.

\section{Conclusion}

LAB with great GABA production ability was isolated from Kimchi. MRS medium containing MSG as a source of glutamic acid was used in order to select the strains with GABA-producing ability from the isolated strains. Selected K255 strain was identified as Lactobacillus plantarum by the result of API carbohydrate fermentation test and 16S rDNA sequence. The optimum growth temperature of $\mathrm{K} 255$ was $37^{\circ} \mathrm{C}$ and cultures took $13 \mathrm{~h}$ to reach the $\mathrm{pH}$ 4.4. L. plantarum $\mathrm{K} 255$ could survive in the antibiotic circumstance with high concentration and didn't produce carcinogenic enzyme such as $\beta$-glucuronidase. Moreover, it was comparatively tolerant to bile juice, acid and displayed resistance to the pathogenic strains. These results demonstrate that $L$. plantarum $\mathrm{K} 255$ could be an excellent strain for the production of functional products with GABA production.

\section{Acknowledgement}

This study was supported by a grant from the Korea Food Research Institute (project no. E0131301).

\section{References}

1. Bae, M. O., Kim, H. J., Cha, Y. S., Lee, M. K., and Oh, S. H. (2009) Effects of Kimchi lactic acid bacteria Lactobacillus sp. OPK2-59 with high GABA producing capacity on liver function improvement. J. Korean Soc. Food Sci. Nutri. 38,
1499-1505.

2. Beaud, D., Tailliez, P., and Anba-Mondoloni, J. (2005) Genetic characterization of the $\beta$-glucuronidase enzyme from a human intestinal bacterium, Ruminococcus gnavus. Microbiology 151, 2323-2330.

3. Booth, I. R. (1985) Regulation of cytoplasmic $\mathrm{pH}$ in bacteria. Microbiol. Rev. 49, 359-378.

4. Buchanan, R. E. and Gibbons, N. E. (1974) Bergey's manual of determinative bacteriology. 8th ed, Waverly Press, Inc., Baltimore, pp. 576-593.

5. Cheigh, H. S. and Park, K. Y. (1994) Biochemical, microbiological, and nutritional aspects of Kimchi (Korean fermented vegetable products). Crit. Rev. Food Sci. 34, 175-203.

6. Cho, J. H., Lee, D. Y., Yang, C. N., Jeon, J. I., Kim, J. H., and Han, H. U. (2006) Microbial population dynamics of Kimchi, a fermented cabbage product. FEMS Microbiol. Lett. 257, 262-267.

7. Clark, P. A., Cotton, L. N., and Martin, J. H. (1993) Selection of bifidobacteria for use as dietary adjuncts in cultured dairy foods: II. Tolerance to simulated $\mathrm{pH}$ of human stomachs. $\mathrm{Cul}$. Dairy Prod. J. 28, 11-14.

8. Gilliland, S. E. and Speck, M. L. (1977) Antagonistic action of Lactobacillus acidophilus toward intestinal and foodborne pathogens in associative cultures. J. Food Prot. 40, 820-823.

9. Gilliland, S. E. and Walker D. K. (1990) Factors to consider when selecting a culture of Lactobacillus acidophilus as a dietary adjunct to produce a hypocholesterolemic effect in humans. J. Dairy Sci. 73, 905-911.

10. Hur, H. J., Lee, K. W., Kim, H. Y., Chung, D. K., and Lee, H. J. (2006) In vitro immunopotentiating activities of cellular fractions of lactic acid bacteria isolated from Kimchi and bifidobacteria. J. Microbiol. Biotechnol. 16, 661-666.

11. Jakobs, C., Jaeken, J., and Gibson, K. M. (1993) Inherited disorders of GABA metabolism. J. Inherit. Metab. Dis. 16, 704-715.

12. Jeon, S. R., Song, T. S., Kim, J. Y., Shin, W. C., Her, S. W., and Yoon, S. S. (2007) Identification and characterization of lactic acid bacteria starters isolated from the commercial drink-yogurt products. Korean J. Food Sci. An. 27, 509-516.

13. Kim, J. H., Kwon, M. J., Lee, S. Y., Rye, J. D., Moon, G. S., Cheigh, H. S., and Song, Y. O. (2002) The effect of Kimchi intake on production of free radicals and anti-oxidative enzyme activities in the liver of SAM. J. Korean Soc. Food Sci. Nutr. 31, 109-116.

14. Kim, S. H., Yang, J. Y., Kang, S. A., Chun, H. K., and Park, K. Y. (2007) Current state and improvement for Korean Kim- 
chi industry. Food Indus. Nutr. 12, 7-13.

15. Kim, Y. J., Jang, S. J., Park, J. M., Kim, C. U., and Park, Y. S. (2010) Culture conditions of garlic resistant lactic acid bacteria for feed additives. Food Eng. Progress 14, 65-74.

16. Kirjavainen, P. V., Ouwehand, A. C., Isolauri, E., and Salminen, S. J. (1998) The ability of probiotic bacteria to bind to human intestinal mucus. FEMS Microbiol. Lett. 167, 185189.

17. Lee, N. K., Yun, C. W., Kim, S. W., Chang, H. I., Kang, C. W., and Paik, H. D. (2008) Screening of lactobacilli derived from chicken feces and partial characterization of Lactobacillus acidophilus A12 as animal probiotics. J. Microbial. Biotechnol. 18, 338-342.

18. Lee, Y. K. and Salminen, S. (1995). The coming age of probiotics. Trends Food Sci. Technol. 6, 241-245.

19. Lim, S. D., Kim, K. S., and Do, J. R. (2011) Physiological characteristics and production of vitamin $\mathrm{K}_{2}$ by Lactobacillus fermentum LC272 isolated from raw milk. Korean J. Food Sci. An. 31, 513-520.

20. Manyam, B. V., Katz, L., Hare, T. A., Kaniefski, K., and Tremblay, R. D. (1981) Isoniazid induced elevation of cerebrospinal fluid (CSF) GABA levels and effects on chorea in huntington's disease. Ann. Neurol. 10, 7-35.

21. Matsumoto, M., Ohishi, H., and Benno, Y. (2004) $\mathrm{H}^{+}$-ATPase activity in bifidobacterium with special reference to acid tolerance. Int. J. Food Microbiol. 93, 109-113.

22. Mcdonald, L. C., Fleming, H. P., and Hassan, H. M. (1990) Acid tolerance of Leuconostoc mesenteroides and Lactobacillus casei. Appl. Environ. Microbial. 53, 2124-2128.

23. Medina, R., Katz, M., Gonzalez, S., and Oliver, G. (2001) Characterization of the lactic acid bacteria in ewe's milk and cheese from Northwest Argentina. J. Food Prot. 64, 559-563.

24. Oh, S. H., Kim, H. J., Kim, Y. H., Yu, J. J., Park, K. B., and Jeon, J. I. (2008) Changes in some physico-chemical properties and $\gamma$-aminobutyric acid content of Kimchi during fermentation and storage. J. Food Sci. Nutr. 13, 219-224.
25. Oh, S. H. and Yu, J. J. (2011) $\gamma$-Aminobutyric acid production and glutamate decarboxylase activity of Lactobacillus sakei OPK2-59 isolated from Kimchi. Korean J. Microbiol. 47, 316322.

26. Rojo-Bezares, B., Saenz, Y., Poeta, P., Zarazaga, M., RuizLarrea, F., and Torres, C. (2006) Assessment of antibiotic susceptibility within lactic acid bacteria strains isolated from wine. Int. J. Food Microbiol. 111, 234-240.

27. Saikusa, T., Horino, T., and Mori, Y. (1994) Accumulation of $\gamma$-aminobutyric acid (GABA) in the rice germ during water soaking. Biosci. Biotech. Biochem. 58, 292-2291.

28. Succi, M., Tremonte, P., Reale, A., Sorrentino, E., Grazia, L., and Pacifico, S. (2005) Bile salt and acid tolerance of Lactobacillus rhamnosus strains isolated from Parmigiano Reggiano cheese. FEMS Microbiol. Lett. 244, 129-137.

29. Tsushida, T. and Murai, T. (1987) Conversion of glutamic acid to g-aminobutyric acid in tea leaves under anaerobic conditions. Agric. Biol. Chem. 51, 2865-2871.

30. Ueno, H. (2000) Enzymatic and structural aspects on glutamate decarboxylase. J. Mol. Catal. B-Enzym. 10, 67-79.

31. Vaiva, G., Thomas, P., Ducrocq, F., Fontaine, M., Boss, V., Devos, P., Rascle, C., Cottencin, O., Brunet, A., Laffargue, P., and Coudemand, M. (2004) Low posttrauma GABA plasma levels as a predictive factor in the development of acute posttraumatic stress disorder. Biol. Psychiat. 55, 250-254.

32. Ventura, M., Canchaya, C., van Sinderen, D., Fitzgerald, G. F., and Zink, R. (2004) Bifidobacterium lactis DSM 10140: identification of the atp (atpBEFHAGDC) operon and analysis of its genetic structure, characteristics, and phylogeny. Appl. Environ. Microbiol. 70, 3110-3121.

33. Wong, C. G. T., Bottiglieri, T., and Snead, O. C. (2003) GABA, $\gamma$-hydroxybutyric acid, and neurological disease. Ann. Neurol. 54. S3-S12.

34. Zhang, G. and Bown, A.W. (1997) The rapid determination of gamma aminobutyric acid. Phytochem. 44, 1007-1009.

(Received 2013.4.1/Revised 2013.9.16/Accepted 2013.9.26) 